\title{
An assessment of the impact of different land use activities on water quality in the upper Olifants River catchment
}

\author{
JM Dabrowski* and LP de Klerk \\ CSIR, Natural Resources and the Environment, Meiring Naude Road, Pretoria 0001, South Africa
}

\begin{abstract}
Routine sampling of water quality was conducted at sites along a longitudinal gradient from upstream to downstream in the Olifants River to determine spatial trends in nutrient and metal concentrations and to relate these trends to changes in land use activities in the catchment. In addition, once-off sampling was conducted at a number of sites located downstream of current mining, abandoned mining, agriculture, wastewater treatment works (WWTWs) and industry. Nutrient concentrations were relatively high and a number of sites within the catchment had average N:P ratios that were indicative of eutrophic to hypertrophic conditions. Routine and once-off sampling indicated that wastewater treatment works contribute high nutrient loads to the system. Trend analysis of Department of Water Affairs (DWA) data indicated significant positive trends in ortho-phosphate at 12 of 14 stations in the catchment. An increase in sulphate concentrations from upstream to downstream indicates that mining activities have a progressively greater impact on water quality with increasing distance downstream. While dissolved metal concentrations frequently exceeded chronic and acute effect aquatic ecosystem health guidelines (particularly aluminium, copper and zinc), there was no observable trend from upstream to downstream. Onceoff sampling showed high variability in water quality parameters downstream of current mining activities, and some sites showed higher metal concentrations in comparison to other land use activities. However, the contribution of current mining activities to metals is low in comparison to the contribution from abandoned mines. Hydrological data showed that acidic rivers contribute proportionally higher flow volumes in comparison to neutral rivers during the drier winter months, which may significantly impact on the lower stretches of the upper Olifants River and into Loskop Dam. A prolonged drought period will most likely result in severe impacts to the lower reaches of the Olifants River and to Loskop Dam. Improved management and maintenance of wastewater treatment works and rehabilitation and/or treatment of abandoned mines and associated acid mine drainage are crucial. Proper rehabilitation of current mining activities is essential to avoid or minimise acid mine drainage related impacts in the future.
\end{abstract}

Keywords: acid mine drainage, land use, metals, nutrients, Olifants River

\section{INTRODUCTION}

A number of land and water use activities that take place in the upper Olifants River system are of strategic importance to South Africa (e.g., mining, agriculture, power generation). These activities rely heavily on a variety of goods and services that they derive from the aquatic ecosystems in the area. The Olifants River has, however, been described as one of the most polluted rivers in southern Africa, due to the number of anthropogenic stressors that are present in the catchment (Grobler et al., 1994). These stressors include intensive coal mining activities (Hobbs et al., 2008), coal-fired power generation (Dabrowski et al., 2008), industrial activities (e.g., chemical manufacturers, chrome and steel smelters) and agriculture, combined with a general decline in the operation and management of wastewater treatment infrastructure, especially sewage treatment (DWA, 2011a).

The pollutants generated by these activities include general acidification of the system and the input or mobilisation of heavy metal ions plus sulphates and other contaminants via acid mine drainage (Bell et al., 2001; Hobbs et al., 2008); potential acid rain resulting from poor air quality (Rodhe et al., 2002); industrial effluent containing a variety of potential

To whom all correspondence should be addressed.

iri +27 12841 4387; fax: +27 12841 3954;

e-mail: jdabrowski@csir.co.za

Received 22 May 2012; accepted in revised form 22 March 2013. pollutants; excessive nutrient inputs (phosphorus and nitrogen) from agricultural activities and sewage effluent (De Villiers and Thiart, 2007; Oberholster et al., 2010a); and microbiological pollution from intensive agriculture (e.g., feedlots) and sewage effluent. Associated with these key water quality parameters are threshold concentrations which, if regularly exceeded, can result in harmful impacts on aquatic ecosystems and human health. Research and field observations indicate that these thresholds are increasingly under threat. With respect to the upper Olifants catchment, the presence of this 'cocktail' of pollutants has recently manifested in a number of critical ecological and human health concerns further downstream in the catchment, most notably in Loskop Dam. Studies performed in the upper Olifants catchment have documented the presence of various heavy metals in fish tissue (Coetzee, et al., 2002). Over the past 15 years, Loskop Dam has had a history of isolated incidents of fish mortality at different times of the year and with different durations (Driescher, 2007; Asthon, 2010). These incidents became more frequent from 2003 to 2008 and have coincided with crocodile mortalities and a population decline from \pm 80 individuals to a total of 4 in 2010 (Ashton, 2010). The precise cause of these mortalities is currently unknown. In 2008 a large number of crocodile mortalities were recorded in the lower Olifants River in the Kruger Park. These deaths were ascribed to pansteatitis although the exact cause of this condition in the crocodiles is currently unknown. Fish sampling in July 2009 indicated high concentrations of aluminium and iron in fish organs as well as tumour formation and severe liver necrosis 


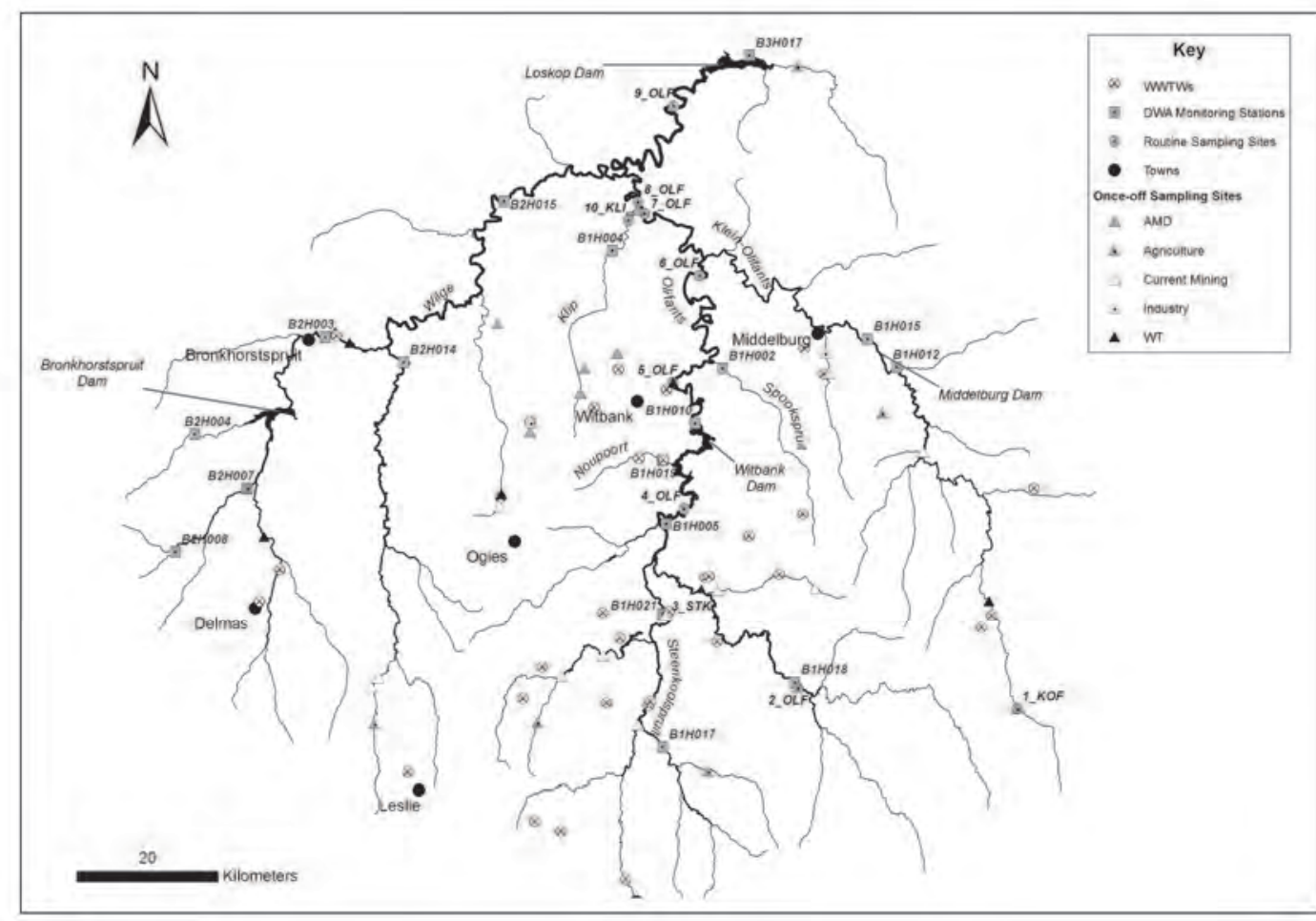

Figure 1

Map showing the location of routine, once-off and Department of Water Affairs monitoring sites in the upper Olifants catchment.

in certain fish species in Loskop Dam (Oberholster et al., 2012). The occurrence of massive toxic cyanobacterial blooms in Loskop Dam since 2008 indicates that the system is hypertrophic (Oberholster et al., 2010a) and edible crop plants may be exposed to cyanobacterial toxins via spray irrigation or other forms of watering (Oberholster and Botha, 2011).

With a view to remediation and future catchment management, it is important to link specific water quality impacts to land use activities occurring in the catchment and to prioritise water quality impacts and associated sources at a catchment level. Accordingly, a multiple sampling and data analysis approach was adopted in the upper Olifants catchment to i) prioritise pollutants in the system through routine monitoring and trend analysis of historical water quality data; ii) link specific land use activities occurring in the catchment to water quality impacts; and iii) identify sub-catchments responsible for high loading of pollutants into the upper catchment. A variety of data analysis methods, including analysis of long-term monitoring data from the Department of Water Affairs (DWA), generation of basic statistics and comparison to water quality guidelines, as well as multivariate statistical analyses are used to elucidate relationships between land use activities in the catchment and impacts on water quality. Outputs of these objectives can be used to prioritise pollutants and sources of pollutants in the catchment, which is essential with regard to future catchment management and remediation initiatives as well as in the design of monitoring programmes aimed at identifying the status and trends of water quality in the catchment.

\section{MATERIALS AND METHODS}

\section{Study area}

The study area is located in the upper section of the Olifants Water Management Area (WMA), upstream of Loskop Dam, and comprises the Wilge and upper Olifants secondary catchments (Fig. 1). In addition to analysis of routine DWA monitoring data, two sampling approaches were adopted; routine monitoring at selected sites within the main stem of the Olifants River and once-off sampling at a number of sites downstream of different land use activities located throughout the catchment.

\section{Routine sampling}

Ten sites were selected for the purposes of routine monitoring (Fig. 1). The catchment area of each of the routine monitoring sites was delineated using ArcGIS and the proportion of land use activities upstream of the sampling point was quantified (Table 1) using the National Land Cover dataset for South Africa (Van den Berg et al., 2008). Site 1_KOF is the most upstream site and, while it is downstream of agricultural activity, is assumed to be the least impacted site. Site 2_OLF is also relatively high up in the catchment and is impacted mainly by agriculture and low intensity mining activities. Each site further downstream is collectively impacted on by a greater concentration of mining and urban impacts, including wastewater treatment works (WWTWs). There is a large increase in mining activities between 2_OLF and 4_OLF, after which the relative proportion of total land cover under mining remains relatively constant. Site 5_OLF is located immediately downstream of a sewage effluent discharge point. Site 8_OLF is just downstream of the confluence of the Olifants River with the Klipspruit River and is thus impacted by acid mine drainage. In addition, sites in the Steenkoolspruit (3_STK) and Klipspruit (10_KLP) catchments were selected for the purposes of comparing metal concentrations and loads originating from an area dominated by current (Steenkoolspruit) and abandoned (Klipspruit) mining and associated acid mine drainage. In total, 5 samples were collected from all of the abovementioned sites; once every 2 months over a 10 -month period. These samples are therefore representative of seasonal changes in river hydrology. 


\begin{tabular}{|l|c|c|c|c|c|c|}
\hline \multicolumn{7}{|c|}{$\begin{array}{c}\text { Table 1 } \\
\text { Composition of major land cover categories, in hectares (and percentage of total in parentheses), in } \\
\text { the catchment area upstream of routine monitoring sites located in the upper Olifants catchment }\end{array}$} \\
\hline Site & Agriculture & Bushveld & Forestry & Grassland & Mining & Urban \\
\hline 1_KOF & $3723(43)$ & 0 & 0 & $4949(57)$ & 0 & 0 \\
\hline 2_OLF & $43871(48)$ & $67(0.1)$ & $67(0.1)$ & $47193(51.6)$ & $201(0.2)$ & $45(<0.1)$ \\
\hline 3_STK & $41418(44)$ & $116(0.1)$ & $42(<0.1)$ & $47470(50.5)$ & $3705(3.9)$ & $1321(1.4)$ \\
\hline 4_OLF & $144767(45.7)$ & $847(0.3)$ & $201(0.1)$ & $155557(49.1)$ & $13420(4.2)$ & $2006(0.6)$ \\
\hline 5_OLF & $153104(42.9)$ & $847(0.2)$ & $490(0.1)$ & $178295(50)$ & $19171(5.4)$ & $4637(1.3)$ \\
\hline 6_OLF & $163069(40.9)$ & $1917(0.5)$ & $736(0.2)$ & $205625(51.6)$ & $21601(5.4)$ & $5729(1.4)$ \\
\hline 7_OLF & $263051(40.9)$ & $7513(1.2)$ & $4102(0.6)$ & $331332(51.5)$ & $28044(4.4)$ & $9898(1.5)$ \\
\hline 8_OLF & $271143(39.3)$ & $12127(1.8)$ & $6041(0.9)$ & $356211(51.7)$ & $30920(4.5)$ & $13108(1.9)$ \\
\hline 9_OLF & $422754(37.7)$ & $75371(6.7)$ & $13219(1.2)$ & $557957(49.7)$ & $33372(3.0)$ & $19550(1.7)$ \\
\hline 10_KLI & $7229(19.7)$ & $1897(5.2)$ & $1592(4.3)$ & $19527(53.1)$ & $3065(8.3)$ & $3254(8.6)$ \\
\hline
\end{tabular}

\section{Once-off sampling}

For once-off sampling (Fig. 1), the objective was to select a number of sites downstream of important land use activities in the catchment. These included current mining, abandoned mining, industry, agriculture and WWTWs. The location of WWTWs was identified using the South African Department of Water Affairs GoogleEarth-enabled water quality data exploration tool (DWA, 2011b). Other land use impacts upstream of sampling sites were identified through a combination of existing GIS land cover maps, 1:50 000 topographical maps, GoogleEarth and groundtruthing exercises. The location of abandoned coal mines was determined and mapped in as much detail as possible using information presented in Rapson and Moolman (2004) and 1:50 000 topographical maps. This identified the location of abandoned mines to at least within a cadastral farm boundary scale. In total, 32 sites were selected (10 current mining, 6 abandoned mining, 9 agriculture, 5 WWTWs and 2 industry sites). Water quality samples were collected and field measurements taken at each of the selected sites during a fieldtrip undertaken from 12 to 13 September 2011. Samples are thus representative of low flow conditions.

\section{Department of Water Affairs monitoring sites}

Twelve monitoring stations were selected in the upper and middle Olifants catchment, as well as the Wilge catchment (Fig. 1). Sites were selected on the basis of having both flow and water quality data so as to enable calculation of loads. These sites were located within the main stem of the Olifants River as well as in main tributaries of the river. Tributary sites, in particular, were chosen in order to identify the main sub-catchments responsible for high loading of pollutants into the main stem of the Olifants River and Loskop Dam.

\section{Sampling and analysis}

On arrival at each sampling site, water temperature, dissolved oxygen, $\mathrm{pH}$ and electrical conductivity values were measured in situ at the water surface using a Thermo 5 star $\mathrm{pH} / \mathrm{RDO} /$ Conductivity meter set. Water samples were collected at each site for standard chemical analysis. All water samples were collected in pre-rinsed, $1 \ell$ polyethylene bottles and placed on ice in the dark, without the addition of any preservatives. Samples were then frozen until they were delivered to the accredited CSIR Analytical Laboratory in Stellenbosch. Samples were filtered through $0.45 \mu \mathrm{m}$ pore size Whatman filters prior to being analysed for dissolved nutrients, metals and major ions using standard methods (APHA, 1992). Concentrations of aluminium (Al), arsenic (As), cadmium $(\mathrm{Cd})$, iron $(\mathrm{Fe})$, manganese $(\mathrm{Mn})$, nickel $(\mathrm{Ni})$ selenium $(\mathrm{Se})$, vanadium $(\mathrm{V})$, zinc $(\mathrm{Zn})$ and copper $(\mathrm{Cu})$ were determined using inductively coupled plasma mass spectrometry (ICP-MS). Detection limits were $1 \mu \mathrm{g} / \ell$ (apart from Cd which was $0.05 \mu \mathrm{g} / \ell$ ). All major ions, except chloride, were analysed using inductively coupled plasma optical emission spectrometry (ICP-OES). Chloride and all dissolved nitrogen and phosphorus forms were measured using a flow injection analyser (FIA). Ammonium $\left(\mathrm{NH}_{4}^{+}\right)$ concentrations were used to estimate the concentration of dissolved ammonia $\left(\mathrm{NH}_{3}\right)$ concentrations as recommended by the Department of Water Affairs and Forestry (DWAF) guidelines for the aquatic ecosystem (DWAF, 1996). Detection limits for all the aforementioned constituents were $0.1 \mathrm{mg} / \ell$.

\section{Data analysis}

\section{Routine sampling and once-off sampling}

Data collected during the five sampling events were plotted as box and whisker plots from upstream to downstream so as to determine changes in water quality parameters along the length of the river. The $10^{\text {th }}$ (bottom whisker), $25^{\text {th }}$ (bottom of box), $50^{\text {th }}$ (line through box), $75^{\text {th }}$ (top of box) and $90^{\text {th }}$ (top whisker) percentiles of measured water quality parameters were presented. Relevant endpoints were compared to existing water quality guidelines for the aquatic ecosystem (DWAF, 1996) so as to prioritise pollutants that potentially pose the greatest risk to the aquatic ecosystem. Where applicable, the Target Water Quality Range (TWQR), Chronic Effect Value $(\mathrm{CEV})$ and the Acute Effect Value (AEV) guidelines were used. For metals the $90^{\text {th }}$ percentile was compared to these guidelines (DWAF, 1996), while average values were used in the case of nutrients.

A multivariate statistical approach was adopted to assess associations between sites (representative of different land use activities) and median measurements of specific water quality variables collected during routine sampling. Ordination of sites by water quality variables was performed by principal component analysis (PCA), using the CANOCO software programme. A PCA was used as the length of the gradient in the data set was less than 4 standard deviations, indicating a linear relationship between sites and water quality. The same approach was adopted to assess associations between sites and specific water quality variables measured during the once-off 

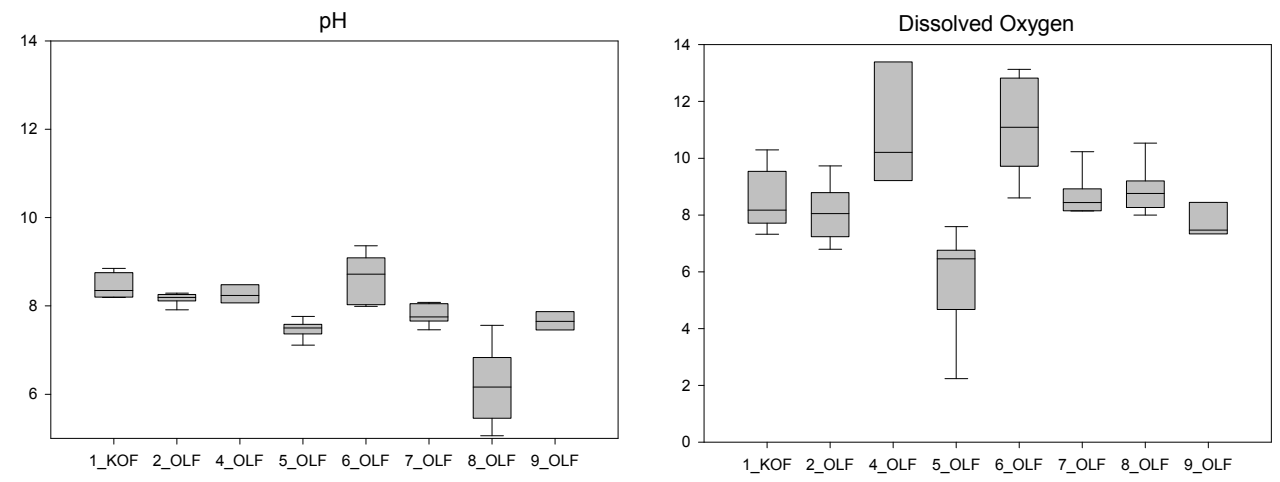

Figure 2

Box and whisker plots of $\mathrm{pH}$ and dissolved oxygen concentration ( $\mathrm{mg} / \mathrm{\ell}$ ) measurements at routine monitoring sites along the upper Olifants River $(n=5)$.
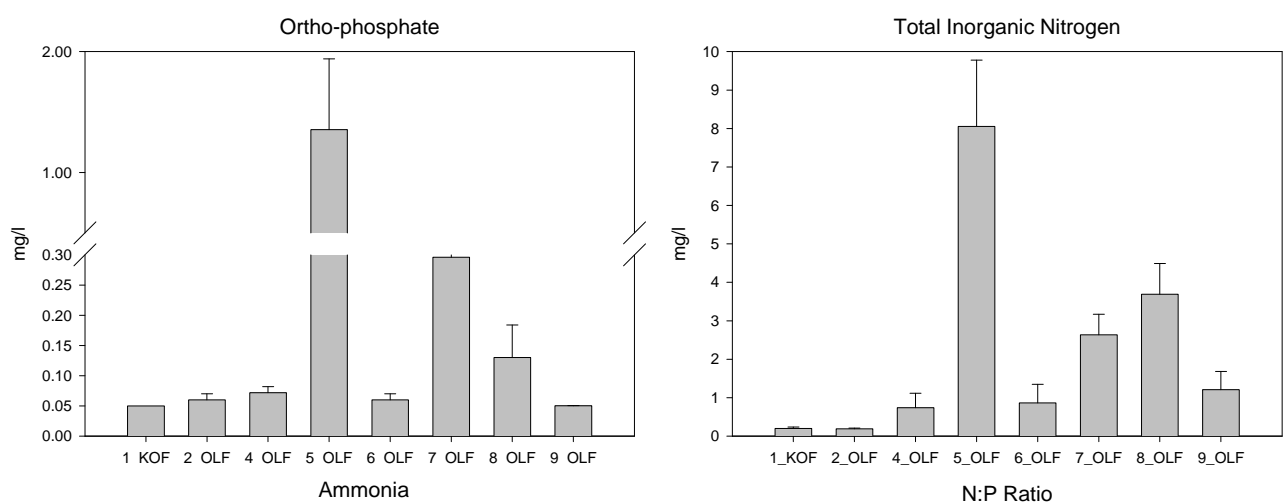

Figure 3

Mean concentrations (orthophosphate, total inorganic nitrogen and ammonia) and $\mathrm{N}: P$ ratios of nutrients measured at routine
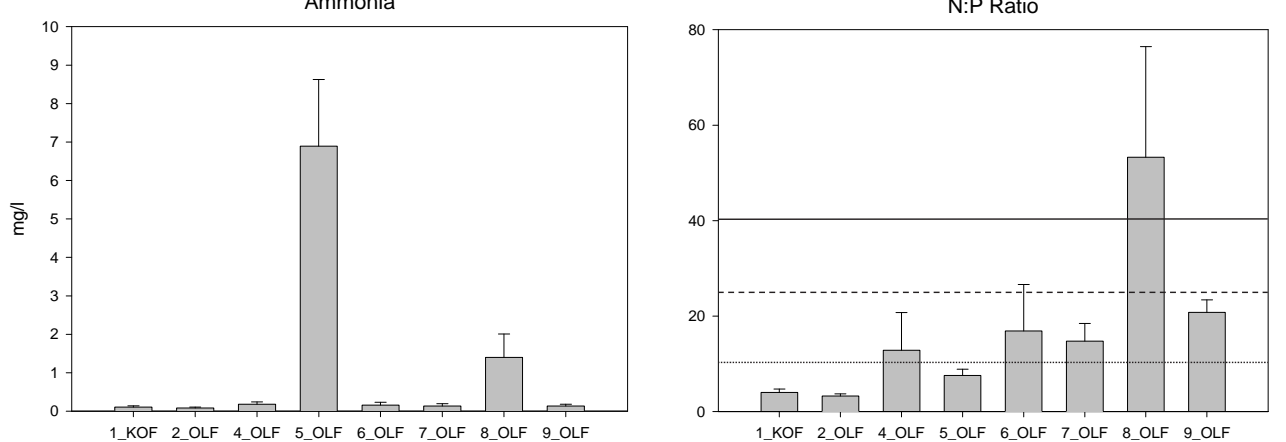

monitoring sites along the upper Olifants River $(n=5)$. Solid, dashed and dotted lines are representative of eutrophic, mesotrophic and oligotrophic status, respectively.

sampling programme. Routine data collected from the Klipspruit and Steenkoolspruit were plotted as a time series. In addition, flow data from DWA, together with measured water quality data, were used to calculate estimated annual metal loads originating from these two catchments. A Monte Carlo analysis, using 10000 iterations, was used to simulate and compare loads of selected water quality pollutants based on observed ranges of measured water quality and flow data.

\section{Department of Water Affairs monitoring data}

Historical water quality data from 1972 to 2010 and flow data from 2000 to 2008 for the 12 DWA monitoring stations were obtained from online DWA databases (DWA, 2011b, c). Boxplots of the minimum (bottom whisker), 25th percentile (bottom of box), median (line through box), 75th percentile (top of box) and maximum concentrations (top whisker) of indicator water quality variables (phosphates, nitrates, sulphates, TDS and $\mathrm{pH}$ ) were generated using GraphPad Prism (version 4.03). Statview was used to subject the data to Kendall correlation analysis to determine significant $(p \leq 0.05)$ positive (Tau value is positive) and negative (Tau value is negative) trends. The FLUX programme (Walker, 1996) was then used to calculate annual loads from flow and water quality data at each station. These loads were used to calculate a mean annual load at each station.

\section{RESULTS}

\section{Routine monitoring}

\section{Field measurements}

The median $\mathrm{pH}$ (Fig. 2) for most sites was above 7, with sites 1_KOF, 2_OLF, 4_OLF and 7_OLF being comparably higher (above 8 ). The exception was 8_OLF, which showed noticeably lower $\mathrm{pH}$ values, with almost $50 \%$ of values being below 6 . At Site 9_OLF further downstream, $\mathrm{pH}$ values generally increased to the neutral to alkaline range. Dissolved oxygen concentrations were generally high, with median values exceeding 8 $\mathrm{mg} / \ell$. Sites 4_OLF and 6_OLF in particular showed very high dissolved oxygen concentrations with median values exceeding $10 \mathrm{mg} / \ell$. Site 5_OLF was the exception with $50 \%$ of measured values being below $6 \mathrm{mg} / \ell$.

\section{Nutrients}

In the case of ortho-phosphate and ammonia, the limits of analytical detection $(0.1 \mathrm{mg} / \ell)$ were considerably higher than values provided as a guide of trophic status (for ortho-phosphate) or toxicity (for ammonia) and thus average values for nutrients could not be compared to guidelines for many of the sites. An assessment of trophic status for each site was made 


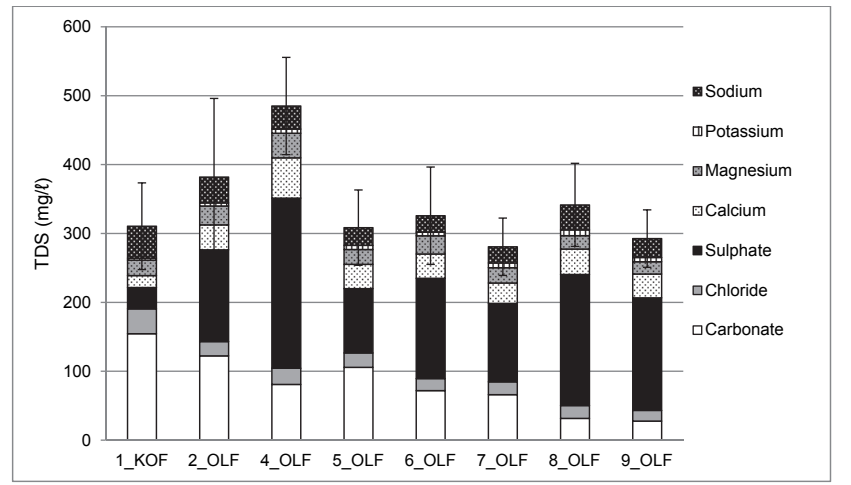

Figure 4

Mean $(n=5)$ total dissolved salts (TDS) concentrations ( \pm standard deviation) and contribution of major ions to total TDS at routine sampling sites along the upper Olifants River.

through calculation of the total inorganic nitrogen to total inorganic phosphorus ratio (N:P) (DWAF, 1996). Site 5_OLF is clearly impacted by nutrients and has high ortho-phosphate, total inorganic nitrogen and ammonia concentrations

(Fig. 3). Sites 7_OLF and 8_OLF also show comparatively higher concentrations of ortho-phosphate and inorganic nitrogen. In the case of 7_OLF, high inorganic nitrogen concentrations are as a result of elevated nitrate and nitrite concentrations, with average ammonia concentrations being comparatively low. The AEV for ammonia is $0.1 \mathrm{mg} / \ell$. This value is exceeded at Sites 5_OLF and 8_OLF. A number of sites (i.e., Sites 1_KOF, 2_OLF and 5_OLF) show average N:P ratios of less than 10, which indicate that the system is impacted (eutrophic or hypertrophic). The remainder of the sites (with the exception of 8 _OLF) show average $\mathrm{N}: \mathrm{P}$ ratios that indicate mesotrophic conditions.

\section{Total dissolved salts and major ions}

Mean total dissolved salts (TDS) concentrations and the mean composition of each of the major ions are presented in Fig. 4. There is an initial increasing trend from 1_KOF to 4_OLF, after which the mean TDS concentrations remain relatively constant (i.e., from 5_OLF to 9_OLF). There is, however, a noticeable trend in the relative composition of major ions that make up the bulk of TDS concentrations. This is particularly noticeable with regard to the anions, with carbonate showing a general decrease in concentration and composition from upstream to downstream and sulphate showing a general increase from upstream to downstream sites.

\section{Metals}

In addition to the metals presented in Fig. 5; antimony, chromium, lead and selenium were also analysed. All four of these metals were either always below detection limits or were well
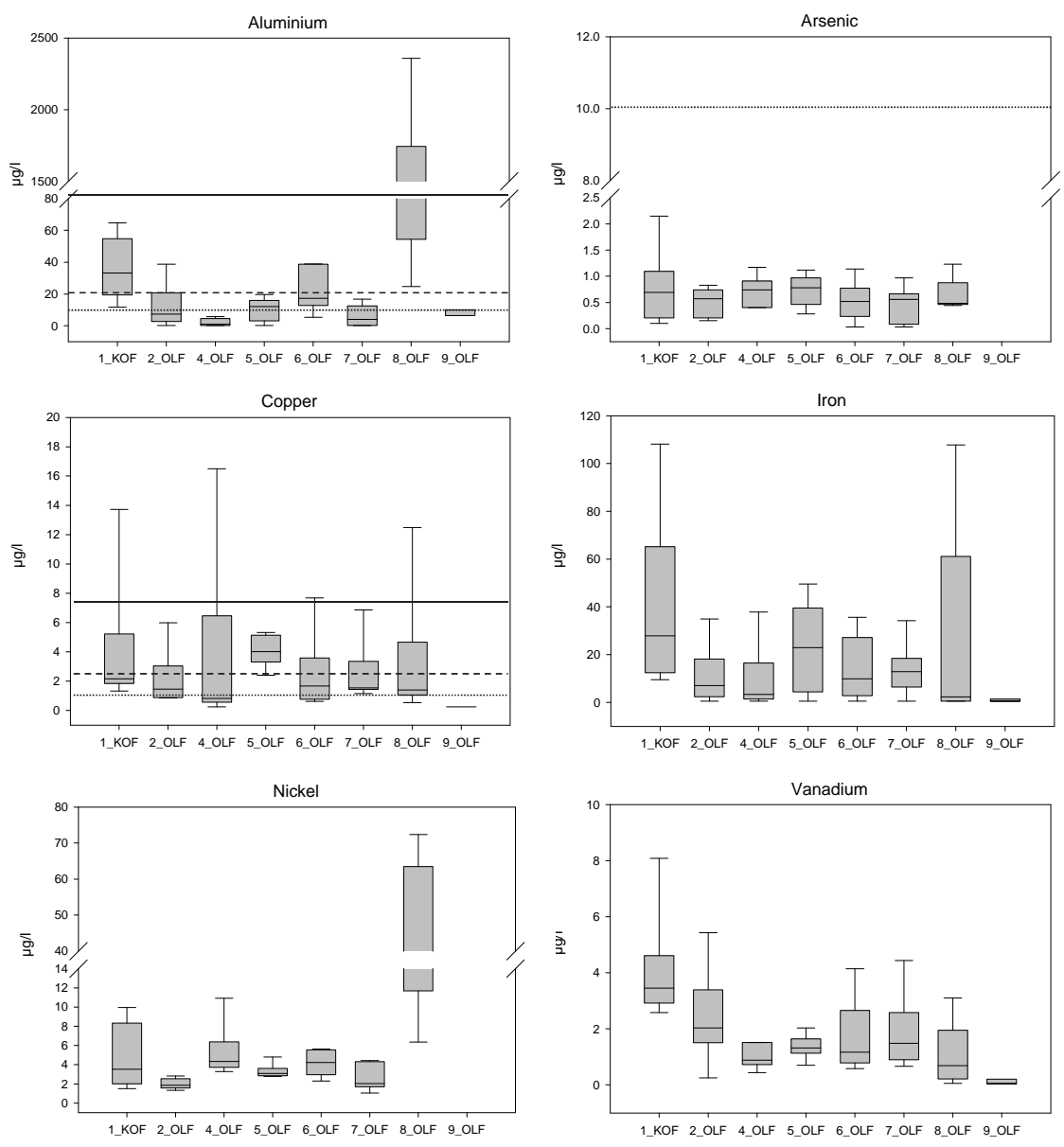
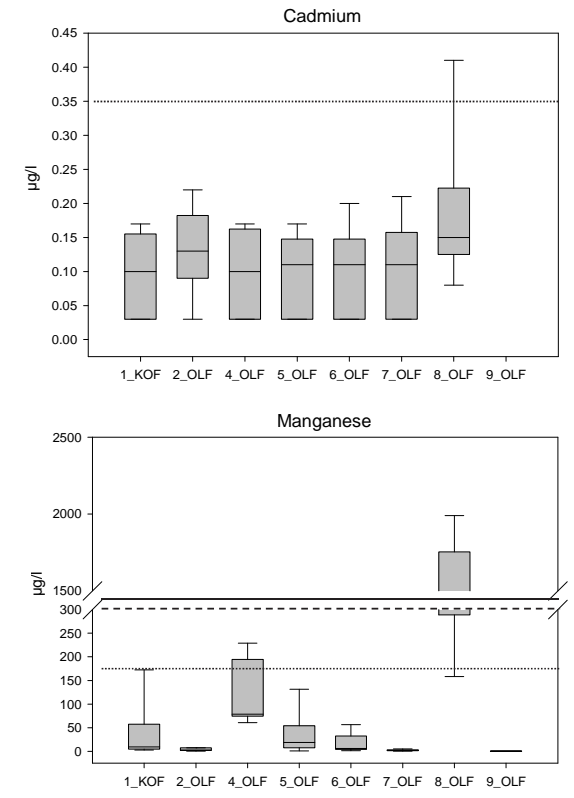

Zinc

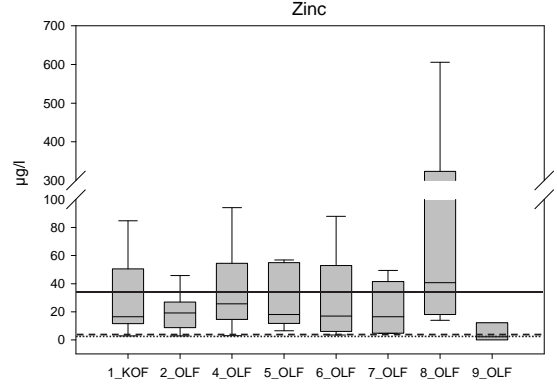

Figure 5

Box and whisker plots of metal concentrations measured at routine monitoring sites along the upper Olifants River $(n=5)$. Dotted, dashed and solid lines represent the TWQR, CEV and AEV guideline values, respectively, as specified by DWAF (1996). 


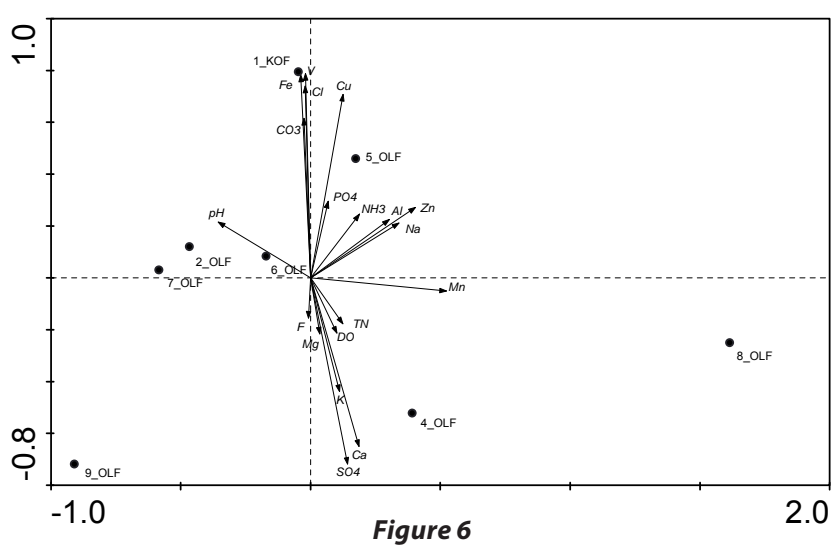

Principal component analysis (PCA) of mean measured water quality parameters (arrows) and sampling sites (black dots) in the main stem of the upper Olifants River.

$\mathrm{pH}$
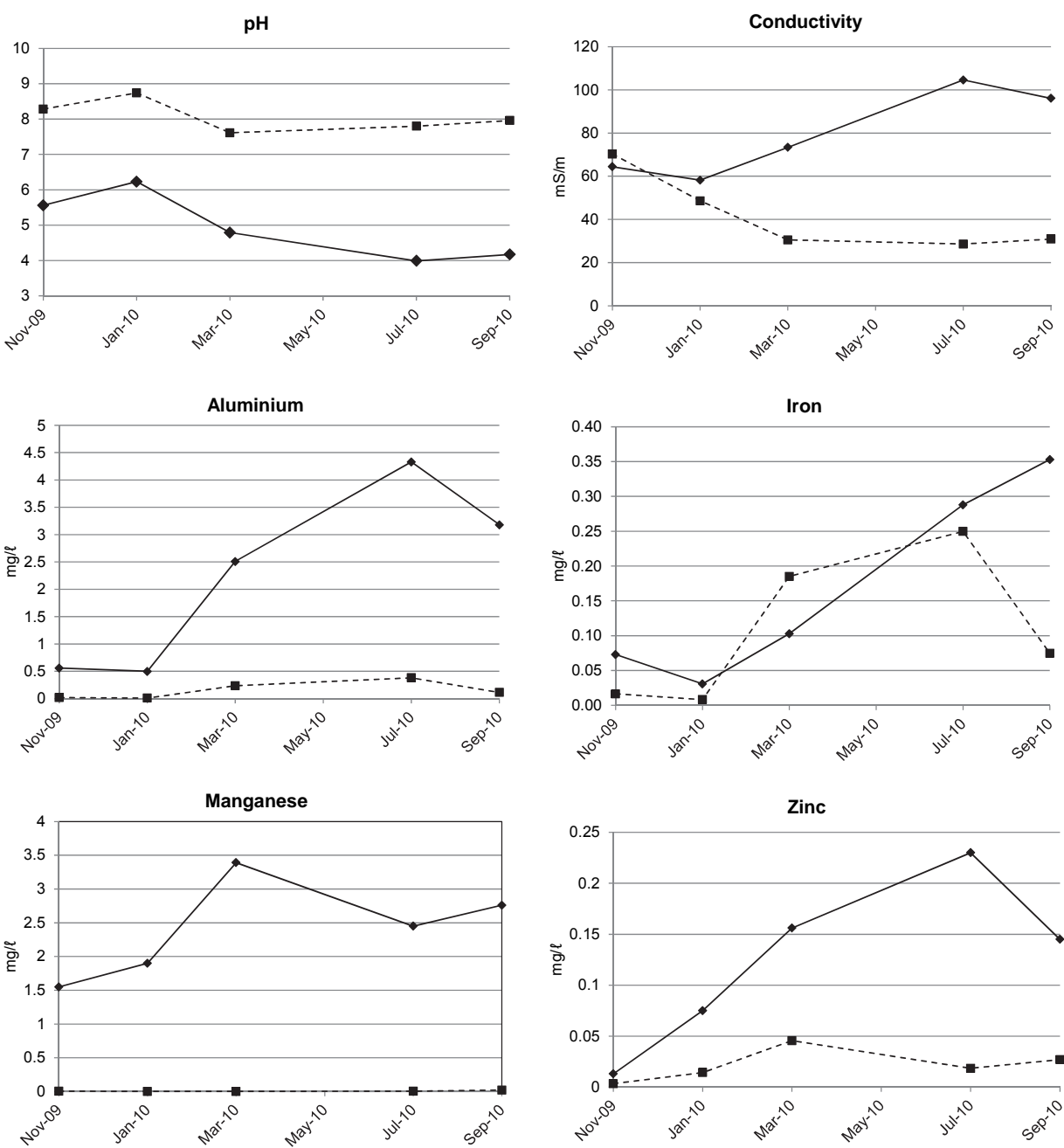

ulphate

Figure 7

Time series plots of $p H_{4}$ conductivity, metals

(aluminium, iron, manganese and zinc) and sulphate measured in the Klipspruit (10_KLl; solid line) and Steenkoolspruit (3_STK; dashed line) rivers during 2011. below relevant water quality guidelines. Additionally, arsenic and cadmium (with the exception of 8_OLF) were both always detected below the TWQR. No guidelines exist for nickel and vanadium in South Africa. Sites 1_KOF, 2_OLF and 6_OLF showed $90^{\text {th }}$ percentile aluminium concentrations above the CEV level (for pH levels greater than 6.5), whilst 8_OLF significantly exceeded the AEV guideline (for $\mathrm{pH}$ levels less than 6.5) more than $25 \%$ of the time. The CEV copper guideline (for hard water, between 120 and $180 \mathrm{mg} \mathrm{CaCO} / \ell$ ) was frequently exceeded at all sites (at least $25 \%$ of the time), with Sites 1_KOF, 4_OLF, 6_OLF and 8_OLF even exceeding the AEV guideline. The DWAF water quality guidelines do not provide a definitive guideline for iron; however, iron concentrations were in most instances (with the exception of Site 8_OLF) lower than that measured at 1_KOF, the most upstream site included in the study. For manganese, Site 8_OLF exceeded the AEV, with all other sites falling within the TWQR. The $90^{\text {th }}$ percentile of zinc concentrations for all sites (except 9_OLF) exceeded the AEV. Site 8_OLF in particular showed very high concentrations of aluminium, manganese, nickel and zinc in comparison to other sites. These high concentrations had significantly decreased at Site 9_OLF, which showed amongst the lowest concentrations for all metals included in the analysis. Apart from Site 8_OLF, there was no observable increase in metal concentrations from upstream to downstream sites.

A PCA of the median concentrations of water quality variables measured at each site over the duration of the study indicate the similarity (or dissimilarity) of sites based on the measured water quality (Fig. 6). In the biplot, the orientation of the arrows (water quality variables) reflects the direction of maximum change of that variable. The longer the arrow, the greater is its influence on the site characterisation. For interpretation purposes, each arrow can be extended backwards through the central origin. Thus, sites (black dots) with perpendicular projections near to or beyond the tip of an arrow will be strongly positively correlated with, and are influenced by, the environmental variable represented by that arrow. Those sites whose projections lie near the origin will be less influenced by the variable in question. The results of the PCA confirm the trends observed in previous figures. 


\begin{tabular}{|c|c|c|c|c|}
\hline \multicolumn{5}{|c|}{$\begin{array}{c}\text { Table } 2 \\
\text { Minimum and maximum annual flow }\left(\mathrm{m}^{3} \times 10^{6}\right) \text { and concentrations (mg/ } \mathrm{l} \text { ) of aluminium, } \\
\text { iron, manganese and zinc (input) used in a Monte Carlo analysis (10 000 iterations) to } \\
\text { estimate annual metal loads ( } \mathrm{kg} / \mathrm{year} \text { ) originating from the Klipspruit and Steenkoolspruit rivers. } \\
\text { Results are reported as average annual loads and the average, } 10^{\text {th }}, 50^{\text {th }} \text { and } 90^{\text {th }} \text { percentile } \\
\text { ratios of Klipspruit to Steenkoolspruit loads (output). }\end{array}$} \\
\hline Monte Carlo Analysis & Aluminium & Iron & Manganese & Zinc \\
\hline \multicolumn{5}{|l|}{ Input } \\
\hline Flow range (Klipspruit) & \multicolumn{4}{|c|}{$18.21-88.42$} \\
\hline Flow range (Steenkoolspruit) & \multicolumn{4}{|c|}{$6.94-144.3$} \\
\hline Concentration range (Klipspruit) & $4.3-0.5$ & $0.35-0.07$ & $3.4-1.6$ & $0.23-0.013$ \\
\hline Concentration range (Steenkoolspruit) & $0.38-0.01$ & $0.25-0.008$ & $0.02-0.002$ & $0.05-0.003$ \\
\hline \multicolumn{5}{|l|}{ Output } \\
\hline Average Load (Klipspruit) (kg/year) & 11093 & 972 & 11354 & 567 \\
\hline Average Load (Steenkoolspruit) (kg/year) & 1289 & 843 & 75 & 161 \\
\hline Ratio (Average) & 27 & 4 & 352 & 9 \\
\hline Ratio $\left(10^{\text {th }}\right.$ percentile $)$ & 2.23 & 0.34 & 53.11 & 0.79 \\
\hline Ratio $\left(50^{\text {th }}\right.$ percentile $)$ & 9.69 & 1.32 & 177.58 & 3.83 \\
\hline Ratio $\left(90^{\text {th }}\right.$ percentile $)$ & 58.92 & 7.86 & 798.05 & 20.97 \\
\hline
\end{tabular}

The PCA grouped Sites 2_OLF, 6_OLF and 7_OLF together and separated the remaining sites as being distinct from this group and each other. Site 1_KOF is characterised by having relatively higher concentrations of dissolved iron, vanadium and copper as well as higher concentrations of carbonate and chloride. Site 5_OLF is characterised by having comparatively higher concentrations of nutrients, particularly total phosphate and ammonia as well as relatively high concentrations of copper and iron. Site 4_OLF is characterised by having the highest concentrations of major ions (including calcium, magnesium, potassium and sulphate). Sites 8_OLF and 9_OLF also show high concentrations of these ions; however, they differ significantly with respect to other water quality parameters. Site 8_OLF is characterised by the highest concentrations of aluminium, manganese, zinc and sodium as well as low $\mathrm{pH}$. In contrast, 9_OLF is characterised by the lowest concentrations of metals and nutrients of all sites monitored. Sites 2_OLF, 6_OLF and 7_OLF are grouped close together, indicating that the water quality at these sites is relatively similar, in spite of the fact that 2_OLF is located quite a bit further upstream and is far less impacted by mining activity.

\section{Comparison of Klipspruit and Steenkoolspruit}

Monitoring data for 2010 show strong seasonal patterns in water quality parameters in the Klipspruit River (Fig. 7). The $\mathrm{pH}$ values showed a tendency to decline during low flow periods (i.e., more acidic conditions). Conductivity and dissolved metal concentrations show a strong tendency to increase during low flow conditions. Concentrations measured at this site were higher than those measured at the Steenkoolspruit, which did not show any seasonal variation in $\mathrm{pH}$, conductivity and metal concentrations. The Monte Carlo analysis of estimated load contributions from these two catchments showed markedly higher loads originating from the Klipspruit catchment (Table 2), particularly for aluminium and manganese, with average annual loads being 27 and 352 times higher than from the Steenkoolspruit, respectively. For $90 \%$ of the time, aluminium and manganese loads from the Klipspruit are 2.23 and 53.11 times higher, respectively, than those from the Steenkoolspruit. Zinc loads from the Klipspruit are also generally higher than from the Steenkoolspruit, while iron loads are relatively similar.
Monthly flow records from flow stations in the upper Olifants catchment were analysed to determine the net acidic flow input. On an annual basis the combined flow of the Spookspruit and Klipspruit rivers exceeds that of the flow output from the Witbank and Middelburg dams into the Olifants and Klein-Olifants rivers, respectively (Fig. 8). This net acidic flow occurs during the drier winter months. During the summer months the net flow is dominated by the more alkaline Olifants and Klein-Olifants rivers.

\section{Once-off monitoring}

The PCA biplot (Fig. 9) groups sampling sites according to their similarity in terms of their water quality signature. The first (horizontal) axis is positively correlated with trace metals and is negatively correlated with $\mathrm{pH}$. The second (vertical) axis is largely characterised by dissolved salts. Three groups of sites could be clearly separated. These are (i) abandoned mining sites, located on the right hand side of the plot; (ii) current mining and industry sites (located towards the bottom, left of the plot); and (iii) a combination of agricultural, current mining and WWTWs, located on the top left portion of the graph. The abandoned mining sites are characterised by having comparatively high concentrations of aluminium, iron, manganese and zinc, and low $\mathrm{pH}$ (i.e., acidic water). There was high variation in water quality downstream of current mining activities. The second group of sites (current mining and industry) were characterised by higher $\mathrm{pH}$ values and very high TDS concentrations. Some of the current mining sites also show metal concentrations that are higher than those associated with agricultural land use and WWTWs (but much lower than abandoned mining sites). Sites 13_CM, 14_CM and 20_CM show relatively higher concentrations of aluminium, copper and iron, while Sites 15_CM, 21_CM and 40_CM show higher concentrations of zinc and manganese. The final group of sites represents a number of land use impacts (including agriculture) and in comparison to other sites included in the analysis has lower concentrations of TDS (and associated ions) and metals (although copper is relatively high at these sites). Phosphate plays a minor role in distinguishing sites (as indicated by the very short length of the arrow). 


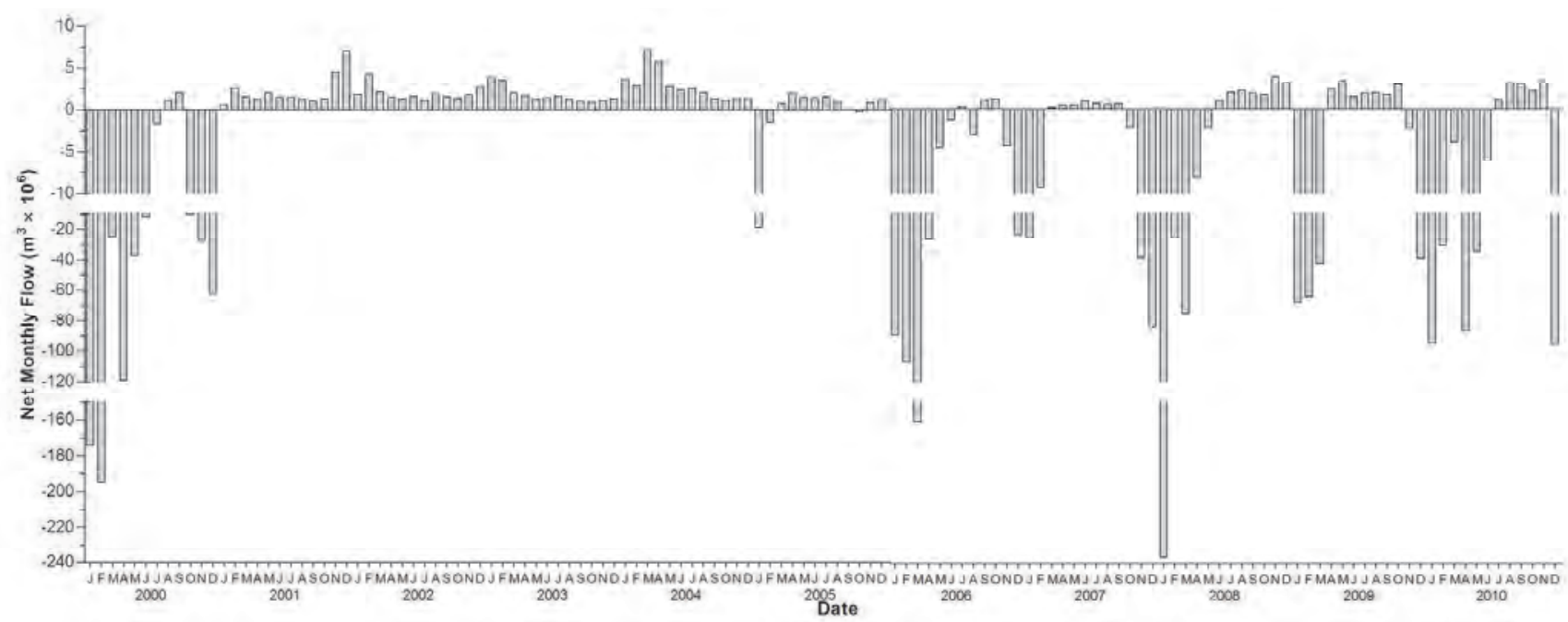

Figure 8

Net monthly flow originating from acidic streams (sum of Klipspruit and Spookspruit) versus alkaline rivers (sum of Olifants and Klein-Olifants). Positive values indicate a net acidic flow and negative values indicate a net alkaline flow.

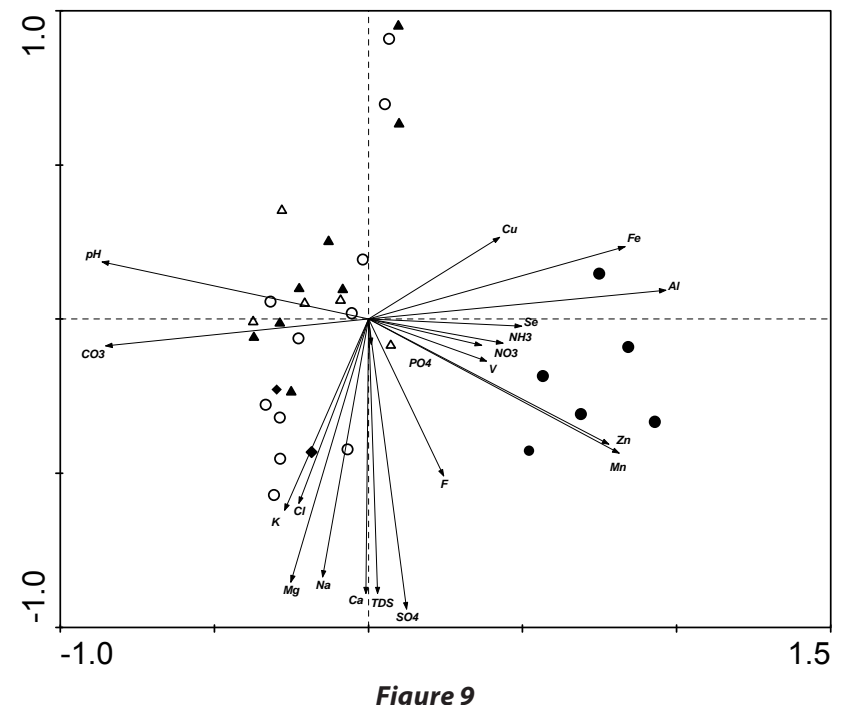

Principal component analysis (PCA) of measured water quality parameters (black arrows) and sampling sites downstream of agriculture (solid triangle), abandoned mining (solid circle) current mining (open circle), industry (solid diamond) and wastewater treatment works (open triangle) in the upper Olifants River catchment.

Figure 10 confirms the results from the PCA with respect to TDS and major ions. Sites downstream of current mining activities showed amongst the highest TDS concentrations of all sites sampled, with sulphate forming the majority of the ionic composition. There is, however, a high amount of variation associated with total TDS concentrations as inferred by the standard deviation. Sites impacted by abandoned mining and industry also show comparatively high TDS concentrations with sulphate also comprising a large proportion of the ionic composition. Sites downstream of agriculture and WWTWs show amongst the lowest TDS concentrations and have a more equal composition of major ions, with carbonate concentrations being noticeably higher in comparison to mining (abandoned and current) and industrial sites.

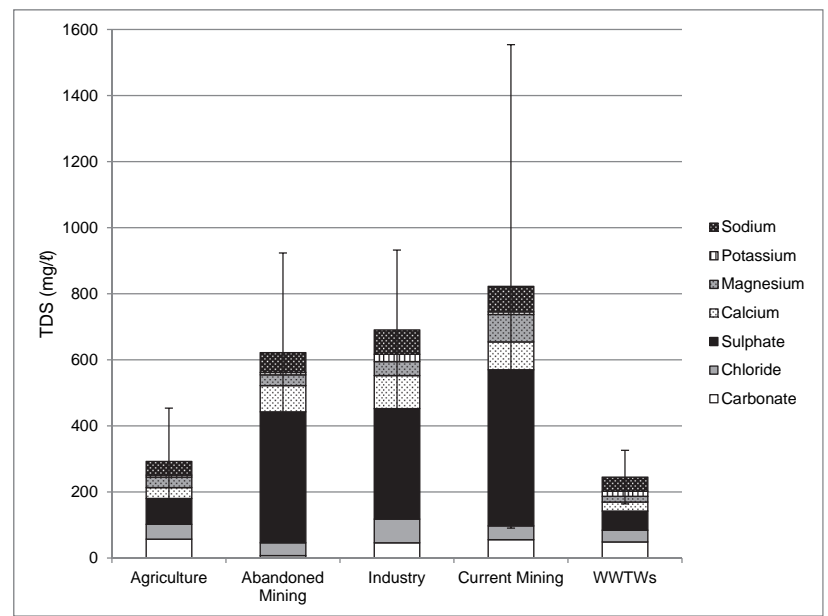

Figure 10

Mean total dissolved salt concentrations ( \pm standard deviation) and contribution of major ions to total TDS at once-off sampling sites representative of agriculture $(n=8)$, abandoned mining $(n=6)$, industry $(n=2)$, current mining $(n=10)$ and wastewater treatment works $(n=5)$ in the upper Olifants River catchment.

\section{Department of Water Affairs monitoring data}

\section{Trends}

Historical water quality data from 1972 to 2010 of the upper and middle Olifants, as well as the Wilge catchment, are indicated in Fig. 11. Significant positive trends were observed for phosphate concentrations at 10 of the 12 selected sites. The other two sites in the upper Olifants River (B1H018) and below Loskop Dam (B3H017) also showed positive trends, but these were not significant. In contrast, a significant increase in nitrate concentrations was observed at only 3 sites, namely, the Steenkoolspruit, Bronkhorstspruit and Wilge River. On the other hand, significant decreasing trends were observed at the following 6 sites: Olifants River (B1H005, B1H010 and B3H017), 
a

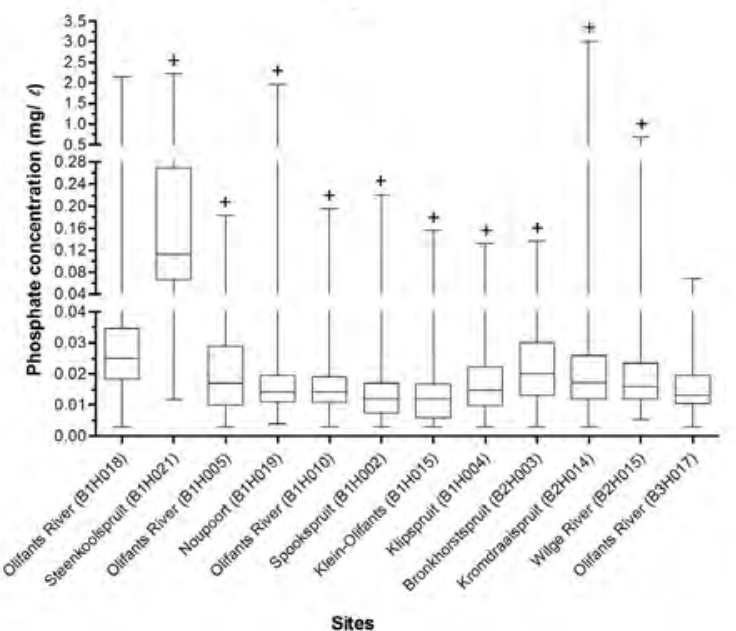

c

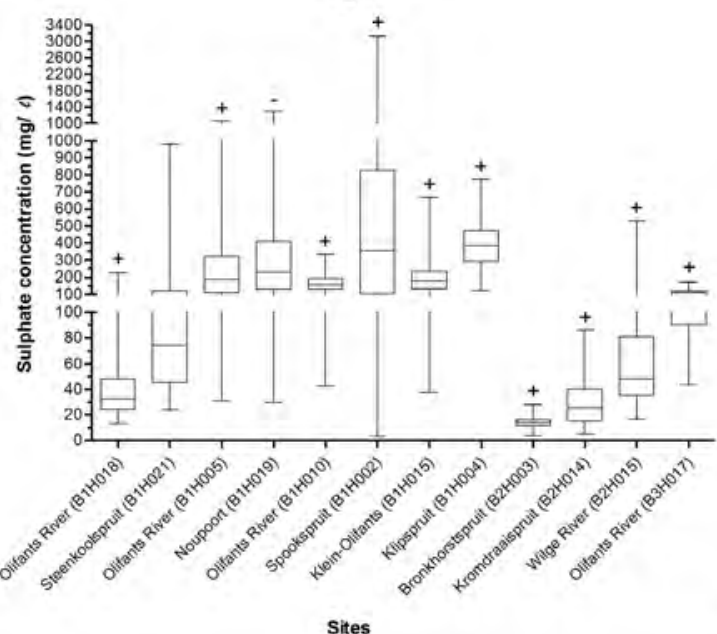

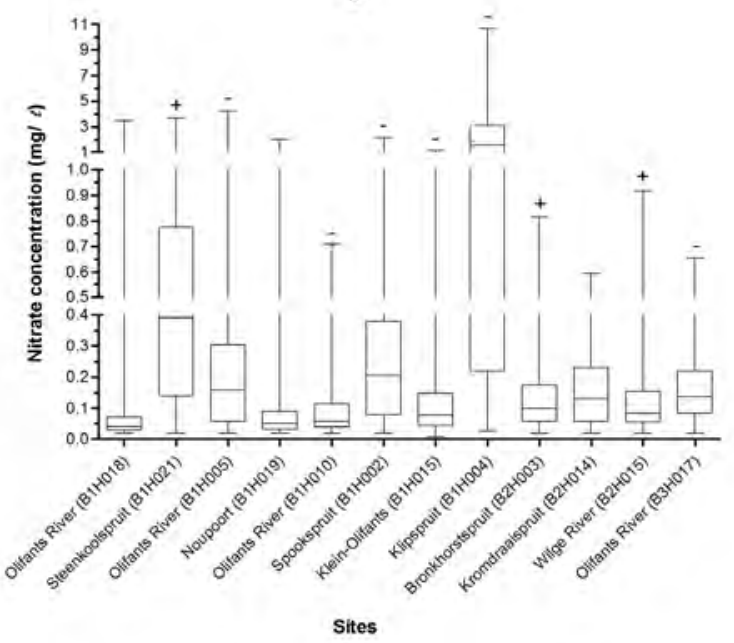

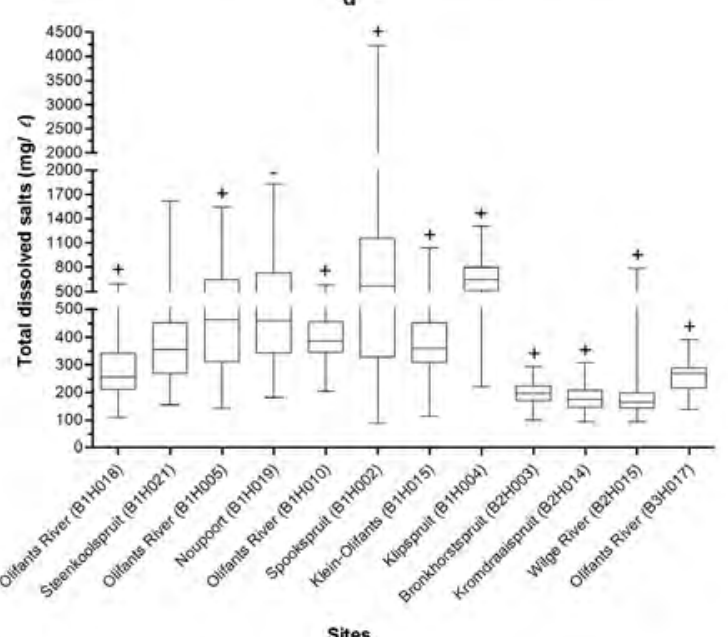

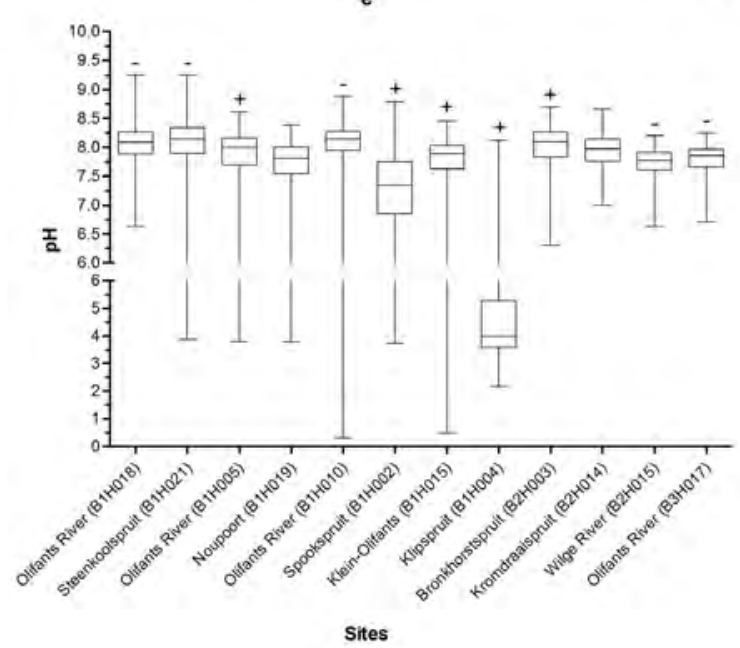

Figure 11

Minimum, 25th, median, 75th and maximum percentiles of phosphate, nitrate, sulphate and total dissolved salts concentrations, and $\mathrm{pH}$, measured at Department of Water Affairs monitoring sites located in the upper Olifants catchment from 1972 to 2010. Positive (+) and negative (-) symbols indicate significant positive and negative trends, respectively.

Spookspruit, Klein-Olifants and Klipspruit. Non-significant positive trends were found at the Olifants River (B1H018), Noupoort and Kromdraaispruit. For the sulphate and TDS concentrations the trends were mostly significantly positive, with the exceptions of Steenkoolspruit and Noupoort (significantly negative). The trend for $\mathrm{pH}$ was significantly positive at 5 sites, namely Olifants River (B1H005), Spookspruit, KleinOlifants, Klipspruit and Bronkhorstspruit. Significant negative trends were observed for Olifants River (B1H018, B1H010 and B3H017), Steenkoolspruit and Wilge River.

\section{Loads}

Mean annual loads from 2000 to 2010 are indicated as boxand whisker plots in Fig. 12. The Steenkoolspruit contributes the greatest phosphate and nitrate loads to the Olifants River, resulting in high loads at $\mathrm{B} 1 \mathrm{H} 005$ (with Klipspruit also contributing high loads of nitrate). The Steenkoolspruit (B1H021), Spookspruit (B1H002), Klipspruit (B1H004), Klein-Olifants and Wilge rivers (B2H015) all contribute comparatively high loads of sulphate and TDS to the main stem Olifants River, resulting in high loading at $\mathrm{B} 1 \mathrm{H} 005$ and $\mathrm{B} 3 \mathrm{H} 017$. For all water 

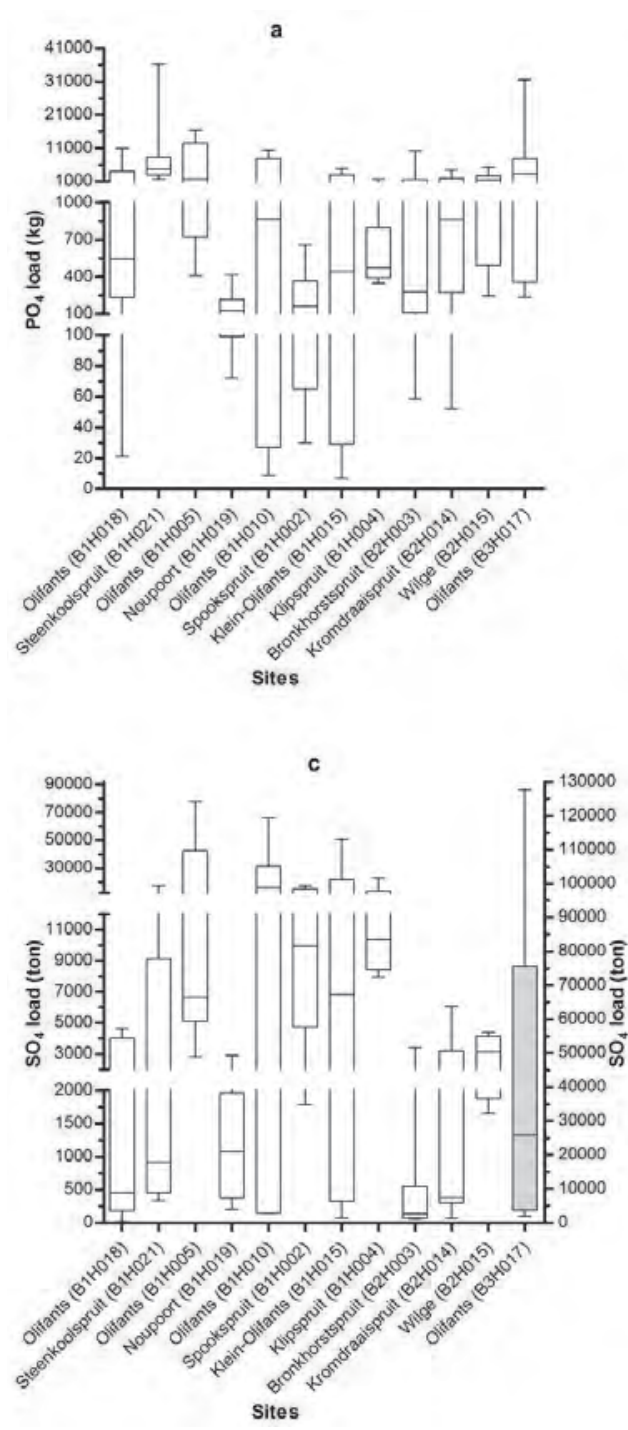
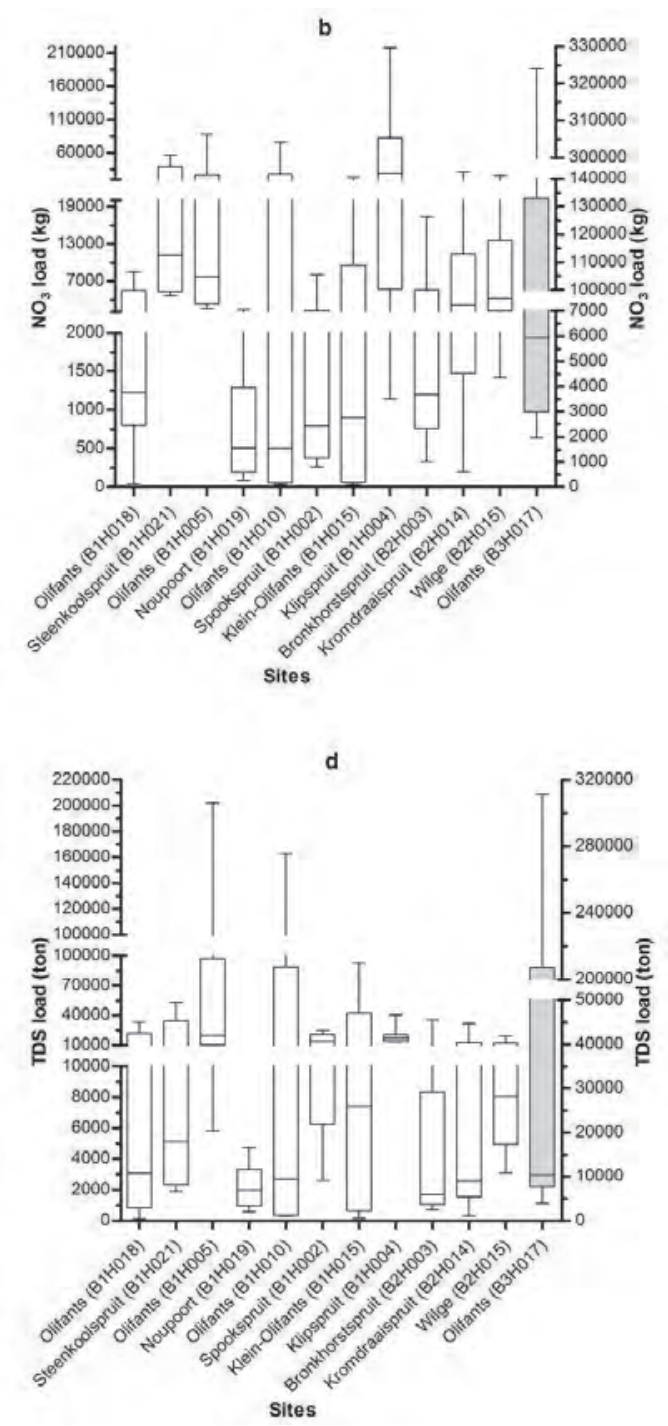

Figure 12

Minimum, $25^{\text {th }}$, median, $75^{\text {th }}$ and maximum percentiles of annual phosphate, nitrate, sulphate and total dissolved solids loads measured at Department of Water Affairs monitoring sites located in the upper Olifants catchment from 2000 to 2010. Shaded bars are read on the right-hand $y$-axis quality parameters, loads decreased below Witbank Dam in comparison to loads calculated upstream of the dam (B1H005), indicating that the dam acts as a sink for nutrients and dissolved salts.

\section{DISCUSSION}

\section{Nutrients}

Nutrient concentrations measured at the three uppermost routine monitoring sites indicate impacted systems with N:P ratios falling within the range of eutrophic to hypertrophic conditions (Fig. 3). This is further supported by the high $\mathrm{pH}$ values recorded at these sites (Fig. 2). Excessive algal growth (brought about by nutrient enrichment) results in utilisation of available dissolved $\mathrm{CO}_{2}$, which reduces the carbonic acid content of the water, thus increasing $\mathrm{pH}$ levels. Further indicators of excessive algal growth are hyper-saturated dissolved oxygen concentrations as a result of high oxygen production by photosynthesising algae (Mainstone and Parr, 2002; Hilton et al., 2006). These conditions exist at a number of sites in the Olifants River, including 1_KOF, 2_OLF, 4_OLF and 6_OLF. Site 5_OLF is located a short distance downstream of the Riverview sewage works in Witbank and shows very high concentrations of ortho-phosphate and nitrogen (Fig. 3), which are commonly associated with sewage input (Jarvie et al., 2006). Average in-stream ortho-phosphate concentrations at this site were in excess of $1 \mathrm{mg} / \ell$ (the current effluent standard for WWTWs in South Africa). Average ammonia concentrations $(6.8 \mathrm{mg} / \ell)$ significantly exceeded the AEV guideline of $0.1 \mathrm{mg} / \ell$. These results indicate that the Riverview WWTW is not operating to an acceptable standard and is releasing unacceptably high concentrations of nutrients into the Olifants River. This is most likely a wider problem in the catchment, with the majority of WWTWs in the upper Olifants catchment scoring very poorly in the annual Green Drop report (DWA, 2011a). Furthermore, while ortho-phosphate did not play a significant role in distinguishing between sites during the once-off sampling exercise (as indicated by the short length of the $\mathrm{PO}_{4}$ arrow in Fig. 9) concentrations downstream of Sites 4_WT and 36_WT measured 4.09 and $7.6 \mathrm{mg} / \ell$, respectively. These exceptionally high concentrations provide further evidence of the general poor standard of WWTWs in the catchment.

Analysis of DWA data provides further evidence of deteriorating water quality with respect to nutrient concentrations. The majority of DWA monitoring sites showed significant increasing trends in ortho-phosphate concentrations and no sites showing a negative trend (Fig. 11). This pattern is in agreement with the analyses of De Villiers and Thiart (2007), who showed that nutrient concentrations are generally increasing in 
large catchments across South Africa. These increasing trends are cause for concern as eutrophication caused by increasing nutrient loads is regarded as one of the most critical issues facing water quality in South Africa. Many dams across the country are in a eutrophic state (Van Ginkel, 2011) and Loskop Dam recently shifted from a mesotrophic to hyper-eutrophic status in 2008 (Oberholster et al., 2010a). In this respect, the identification of sources of nutrients is an important step with regard to managing eutrophication at the catchment level. Calculation of mean annual loads identified the Steenkoolspruit in particular as an important source of phosphate loading (Fig. 12). This corresponds to high loads further downstream (i.e., at B1H005). Witbank Dam clearly acts as a sink for phosphates, as demonstrated by the reduced loads downstream of Witbank Dam (B1H010). Prioritisation of sub-catchments in this manner allows for closer scrutiny of potential sources of pollutants. In the case of the Steenkoolspruit, the high concentration of WWTWs located in the catchment is most likely an important source of phosphates (Fig. 1).

\section{Total dissolved salts and metals}

Site 1_KOF is located relatively high up in the catchment, but is downstream of significant agricultural activity and has TDS concentrations that are similar to those recorded at sites located further downstream in the Olifants River (Fig. 4). Routinely measured TDS concentrations at sites upstream of Witbank Dam indicate a progressive increase in TDS from upstream to downstream. This indicates that changes in land use activities have a progressive and increasing impact on this stretch of river. In particular, the increased mining activity along the length of this section of river (Table 1) most likely impacts on the river, as indicated by the increased sulphate concentrations measured at Sites 2_OLF and 4_OLF. Increased sulphate concentrations are commonly associated with mining activity as a result of the exposure of pyrite to oxygen and water (Bullock and Bell, 1997). Total dissolved salts concentrations are notably lower downstream of Witbank Dam (at Site 5_OLF), indicating that the dam acts as a sink. Total dissolved salts concentrations remain relatively constant after Witbank Dam and are comparable to those measured at Site 1_KOF. However, the relative concentration of sulphate increases along these sites in comparison to other ions. Mining activity increases steadily from 5_OLF further downstream to 7_OLF (Table 1). This is further supported by the once-off sampling, which clearly showed that sulphate comprised the highest proportion of major ions downstream of current mining sites (Fig. 10). Van Zyl et al. (2001) estimated that excess mine water in the upper Olifants catchment amounted to $4.6 \%$ of the total water usage (volume-wise), but contributed $78.4 \%$ of the total sulphate load.

Increased sulphate concentrations along the longitudinal gradient were not associated with increased dissolved metal concentrations up to Site 7_OLF, despite the river flowing through intensive current mining areas, particularly south of Witbank and Middelburg (Fig. 1). While there is an initial increase in mean TDS concentrations upstream of Witbank Dam, concentrations measured at 7_OLF were comparable to 1_KOF (and are in fact slightly lower). Similarly, metal concentrations show a similar trend. Concentrations of aluminium, copper, iron, manganese, nickel, vanadium and zinc at 1_KOF were comparable to, or higher than, concentrations of these metals measured at downstream sites (up to 7_OLF). This could be due to dilution of metals in increasing volumes of water further downstream and measurement of loads would provide a more accurate picture of whether metal input is in fact increasing further downstream.

The fact that 1_KOF showed a relative ionic composition that is typical of a site that is un-impacted by mining activity (i.e., high carbonate and low sulphate concentrations - Fig. 4), yet showed comparatively high metal concentrations, indicates that measured metal concentrations could either originate from sources other than mining (i.e., agriculture or atmospheric deposition) or reflect natural background concentrations derived from the surrounding geology. The CEV value for aluminium was exceeded at 1_KOF, 2_OLF and 6_OLF, while the AEV was exceeded at 8 _OLF. The AEV guideline values for copper and especially zinc were exceeded at many sites along the length of the river. The fact that these guideline values were consistently exceeded, even at the uppermost site in the catchment, could indicate that the guideline values may be unrealistically low. The South African Water Quality guidelines do make provision for modification of guidelines (DWAF, 1996) in relation to site-specific conditions. Aluminium and copper are common elements in rocks and minerals of the earth's crust and do occur naturally in most surface waters (DWAF, 1996) as a result of weathering. The solubility of aluminium is strongly $\mathrm{pH}$ dependent and aluminium may be mobilised to the aquatic environment under acidic $(\mathrm{pH}<6)$ or alkaline $(\mathrm{pH}>8)$ conditions (Gensemer and Playle, 2010). The $\mathrm{pH}$ levels recorded at 1_KOF, 2_OLF, 3_OLF and 6_OLF were frequently above 8 . Another possible explanation for the high metal concentrations could be due to the analytical method. Although the abundance of dissolved elements is commonly quantified by filtering water through $0.45 \mu \mathrm{m}$ filter paper, it is well known that fine particles and colloids smaller than $0.45 \mu \mathrm{m}$ (which interact strongly with metals) may pass through the filter and thus be incorporated and interpreted as part of the dissolved fraction (Hill and Aplin, 2001). Other potential sources of metals at sites high up in the catchment (i.e., 1_KOF) may be from atmospheric deposition. For example, vanadium concentrations at Site 1_KOF were the highest for all sites included in the study. One of the most important sources of atmospheric vanadium is the combustion of coal (WHO, 2000), and the fact that the upper Olifants catchment is the major centre for coal-fired electricity production in the country could suggest that atmospheric deposition may contribute to impaired water quality in the catchment. Analyses of rain water collected during the first year of the study frequently reported concentrations of aluminium, iron, vanadium and zinc (Oberholster et al., 2010b). Given the intensity of mining in the catchment and the fact that these metals are commonly associated as pollutants from such mining activities (Bell et al., 2001), together with the fact that guideline values were frequently exceeded, is reasonable justification to highlight these elements as potential priority pollutants which should be considered in routine monitoring programmes.

The frequency of routine sampling conducted in this study was low and most likely does not account for variability in the system, particularly in association with controlled mine water releases that could potentially result in locally acidic conditions and release high concentrations of metals and sulphates into the system (Van Zyl et al., 2001). The principle of these releases is to release polluted water from current mining activities during periods of high flow, such that the runoff is sufficient to dilute pollutants to acceptable concentrations (Mey and Van Niekerk, 2009). In this respect, performing routine sampling at more frequent intervals during the wet season and analysis of monitoring data from the controlled release scheme will help 
to further clarify the contribution of current mining activities to metal loads in the upper Olifants River. Once-off sampling identified sites downstream of current mining activities that contribute higher metal concentrations relative to other land uses. However, there were also a number of current mining sites grouped together with agricultural and WWTW sites, which were all characterised by having relatively low metal concentrations. This indicates that there is a large amount of variation associated with the water quality downstream of current mining activities. This is obvious from the large amount of variation in TDS concentrations at monitored sites (Fig. 10).

Mining activities and associated impacts are often aggregated to include acid mine drainage from abandoned mines and intentional mine water release from current mining activities. However, acid mine drainage is generally characterised by low $\mathrm{pH}$ water and high salt and metal concentrations (Bell et al., 2001). While high salt concentrations are tolerated, mine water release from existing mines is required to be treated before release such that near-neutral water with low metal concentrations is released (Mey and Van Niekerk, 2009). Once-off sampling illustrated that abandoned mining areas are clearly the most important source of metals in the upper Olifants system. These abandoned mining sites are concentrated within the Klipspruit, Kromdraaispruit, Saalboomspruit and Spookspruit catchments (Fig. 1). The effect of abandoned mining on the Klipspruit River and its influence on the Olifants River is apparent at 8_OLF. This is the only site along the length of the Olifants River that showed metal concentrations that consistently and greatly exceeded guideline values, indicating that acid mine drainage has a significant impact on the Olifants River at this point. The threat of acid mine drainage related impacts is highlighted by the load calculations performed for the Steenkoolspruit and Klipspruit catchments (Fig. 12). While both catchments are a similar size and have a similar area under mining activity, the influence of abandoned mines in the Klipspruit results in significantly higher dissolved metal loads to the Olifants system.

Routine monitoring showed that the Klipspruit is acidic and transports high concentrations of dissolved metals (Fig. 7). This results in a decrease in $\mathrm{pH}$ and in an increase in aluminium, iron, manganese and zinc concentrations, which are significantly higher than their respective AEV guideline values at 8_OLF in the Olifants River. These concentrations are significantly reduced at 9_OLF. This is most likely as a result of dilution by 'cleaner' water in the Wilge River, as well as the gradual precipitation of metals out of solution as the acidic water mixes with the alkaline water of the Olifants River (Short et al., 1990; Kimball et al., 2002). In this respect, the precipitation of metals, their incorporation into the sediment and subsequent transport (either via sediment or as a colloidal suspension) into Loskop Dam, and factors that may influence their mobilisation from dam sediments require further investigation. Witbank Dam clearly acts as a sink for TDS and Loskop Dam most likely performs a similar function. Chronic and acute effects most likely related to pollution have been observed in Loskop Dam through the manifestation of pansteatitis and periodic fish kills (Ashton, 2010). Studies suggest that, under anoxic conditions brought about by eutrophication, metals are generally immobile due to the formation of metal sulphide precipitates (Jackson, 1978; Harrington et al., 1998) and are thus confined to the sediments. However, the high $\mathrm{pH}$ associated with algal blooms in Loskop Dam and the absorption of metals by phytoplankton (Laube et al., 1979) may also result in the mobilisation of metals and their incorporation into the food chain. Similarly, acidic conditions can also mobilise metals from the sediments (Calmano et al., 1993).

In this respect, the influence of the Klipspruit on the mobilisation of metals and other toxic compounds in Loskop Dam should not be underestimated. Analysis of flow records (Fig. 8) shows that, particularly during low-flow winter months, the combined monthly discharge of acidic rivers (i.e., the Klipspruit and Spookspruit) can exceed the flows released from the Witbank and Middelburg dams (i.e., Olifants and KleinOlifants rivers). While other rivers join the Olifants River prior to its entry into Loskop Dam (i.e., the Wilge River and other small streams), it is possible that the flow of the Olifants River may not be sufficient to neutralise the water originating from the Klipspruit. This net acidic flow originating from acid mine drainage is potentially exacerbated by the fact that the $\mathrm{pH}$ is particularly low and metal concentrations considerably higher during low flow conditions (Fig. 7), which is most likely as a result of reduced dilution capacity during this period (Tutu et al., 2008). Acidic water entering the dam can mobilise metals from the sediment and also convert sulphate to $\mathrm{H}_{2} \mathrm{~S}$, which is particularly toxic to aquatic life. Acidic conditions ( $\mathrm{pH}$ 5.9-6.8) were reported at the inflow of Loskop Dam from January to June 2008 (Oberholster et al., 2010a). This coincided with a particularly high net acidic flow from Spookspruit and Klipspruit (Fig. 8). There are a large number of abandoned mines located within the Saalboomspruit and Kromdraaispruit catchments (Fig. 1) which could have a similar effect on the Wilge River during low flow conditions and should be investigated further. These results suggest that low rainfall or drought periods could result in potentially serious consequences with respect to water quality in the lower section of the Olifants River and in Loskop Dam.

The importance of the Klipspruit is emphasised by the analysis of long-term DWA data. The Klipspruit, Spookspruit and Klein-Olifants are clearly the highest contributors of sulphate loads to the Olifants system (Fig. 12). Significant positive trends in sulphate and TDS concentrations at these and the majority of other DWA monitoring stations in the catchment indicate that, at current status quo, the situation is likely to deteriorate (Fig. 11). De Villiers and Mkwelo (2009) found similar trends in their analysis of water quality in the Olifants catchment. This is especially concerning considering the number of new mining applications granted in the catchment. Measurements of $\mathrm{pH}$ show a significant decreasing trend in the Steenkoolspruit and upper Olifants River (B1H010 and B1H018). This together with the fact that very low $\mathrm{pH}$ values have been measured at a number of sites across the catchment indicates that acidic events do occur in current mining areas. Considering the current extent of coal mining in the upper Olifants catchment, the influence of the Klipspruit River highlights the importance of effective management, planning and closure of mines so as to minimise acid mine drainage in the future. The costs and the benefits of acid mine drainage management accrue to different stakeholders at different timeframes. If left unmitigated, the impacts of acid mine drainage impose costs to the wider community of water users; often these costs will need to be borne for decades or generations. On the other hand, while a well-designed acid mine drainage management plan would increase short-term costs for mining companies, it would create long-term benefits to the community, local government, and other stakeholders, and reduce risks to the environment. Recognising the nature of these costs over time, relative to the desired and anticipated benefits, is critical to the development of an acceptable solution to the current water quality situation in the upper Olifants River catchment. 


\section{CONCLUSION}

While dissolved metal concentrations appeared to be elevated throughout the catchment and there was no obvious trend from upstream to downstream, it is important to assess the toxicity of this water through toxicological experiments. In this respect, analysis of the speciation of metals would be useful in assessing toxicity. Furthermore, it is important to determine whether or not metal enrichment of sediment may be taking place. The fate of sediment-bound metals, particularly in sink areas such as Loskop Dam, and their susceptibility to fluctuations in redox conditions and in $\mathrm{pH}$ levels, is crucial with regard to assessing their risk to aquatic ecosystem health. In addition, the relative contribution of the Olifants and Klipspruit rivers to loads of dissolved, colloidal and sediment-bound metal ions is an important step to further quantifying the relative sources of metals transported to Loskop Dam from current and abandoned mining activities. Improved management and maintenance of WWTWs and rehabilitation and/or treatment of abandoned mines and associated acid mine drainage are crucial. Proper rehabilitation of current mining activities is also essential to avoid or minimise acid mine drainage related impacts in the future.

\section{ACKNOWLEDGEMENTS}

Appreciation is expressed to the Olifants River Forum, COALTECH and the National Research Foundation (THRIP Grant) for funding, which made this study possible. Arno de Klerk is acknowledged for collection of water quality samples and collection and capture of in-stream measurements.

\section{REFERENCES}

APHA (AMERICAN PUBLIC HEALTH ASSOCIATION) (1992) Standard Methods for the Examination of Water and Wastewater (19 $9^{\text {th }}$ edn.) APHA (American Public Health Association), AWWA (American Water Works Association), and WPCF (Water Pollution Control Federation), Washington, D.C., USA.

ASHTON PJ (2010) The demise of the Nile crocodile (Crocodylus niloticus) as a keystone species for aquatic ecosystem conservation in South Africa: The case of the Olifants River. Aquat. Conserv.: Mar. Freshwater. Ecosyst. 20 489-493.

BELL FG, BULLOCK SET, HÄLBICH TFJ and LINDSAY P (2001) Environmental impacts associated with an abandoned mine in the Witbank Coalfield, South Africa. Environ. Geol. 45 195-216.

BULLOCK SET and BELL FG (1997) Some problems associated with past mining at a mine in the Witbank coalfield, South Africa. Environ. Geol. 33 (1) 61-71.

CALMANO W, HONG J and FORSTNER U (1993) Binding and mobilization of heavy metals in contaminated sediments affected by $\mathrm{pH}$ and redox potential. Water Sci. Technol. 28 (8-9) 223-235.

COETZEE L, DU PREEZ HH and VAN VUREN JHJ (2002) Metal concentrations in Clarius gariepinus and Labeo umbratus from the Olifants and Klein Olifants River, Mpumalanga, South Africa: Zinc, copper, manganese, lead, chromium, nickel, aluminium and iron. Water SA 28 (4) 433-448.

DABROWSKI JM, ASHTON PJ, MURRAY K, LEANER JJ and MASON RP (2008) Anthropogenic mercury emissions in South Africa: Coal combustion in power plants. Atmos. Environ. 42 6620-6626.

DE VILLIERS S and MKWELO (2009) Has monitoring failed the Olifants River, Mpumalanga? Water SA 35 (5) 671-676.

DE VILLIERS S and THIART C (2007) The nutrient status of South African rivers: Concentrations, trends and fluxes from 1970s to 2005. S. Afr. J. Sci. 103 343-349.

DWA (DEPARTMENT OF WATER AFFAIRS, SOUTH AFRICA) (2011a) Green Drop Report 2010. South African Waste Water
Quality Management Performance. Department of Water Affairs, Pretoria, South Africa.

DWA (DEPARTMENT OF WATER AFFAIRS, SOUTH AFRICA) (2011b) Resource Quality Services Water Quality Data Exploration Tool. URL: http://www.dwa.gov.za/ iwqs/wms/data/000key.asp. (Accessed November 2011).

DWA (DEPARTMENT OF WATER AFFAIRS, SOUTH AFRICA) (2011c) Hydrological Services - Surface Water (Data, Dams, Floods and Flows). URL: http://www.dwaf.gov.za/ hydrology/. (Accessed November 2011).

DWAF (DEPARTMENT OF WATER AFFAIRS AND FORESTRY, SOUTH AFRICA) (1996) South African Water Quality Guidelines. Volume 7: Aquatic Ecosystems. Department of Water Affairs and Forestry, Pretoria, South Africa.

DRIESCHER AC (2007) A Water Quality Study of the Loskop Dam and the Upper Catchment of the Olifants River, Mpumalanga. Unpublished MSc Thesis, University of the Free State, Bloemfontein, South Africa.

GENSEMER RW and PLAYLE RC (2010) The bioavailability and toxicity of aluminium in aquatic environments. Environ. Sci. Technol. 29 (4) 315-450

GROBLER DF, KEMPSTER PL and VAN DER MERWE L (1994) A note on the occurrence of metals in the Olifants River, Easter Transvaal, South Africa. Water SA 20 (3) 195-204.

HARRINGTON JM LAFORCE MJ, REMBER WC, FENDORF SE and ROSENZWEIG RF (1998) Phase associations and mobilization of iron and trace elements in Coeur d'Alene Lake, Idaho. Environ. Sci. Technol. 32 (5) 650-656.

HILL DM and APLIN AC (2001) Role of colloids and fine particles in the transport of metals in rivers draining carbonate and silicate terrains. Limnol. Oceanogr. 46 (2) 331-344.

HILTON J, O'HARE M, BOWES MJ and JONES JI (2006) How green is my river? A new paradigm of eutrophication in rivers. Sci. Total Environ. 365 (1-3) 66-83.

HOBBS P, OELOFSE SHH and RASCHER J (2008) Management of environmental impacts from coal mining in the upper Olifants River catchment as a function of age and scale. Int. J. Water Resour. D. 24 (3) 417-431

JACKSON T (1978) The biogeochemistry of heavy metals in polluted lakes and streams at Flin Flon, Canada, and a proposed method for limiting heavy-metal pollution of natural waters. Environ. Geol. 2 (3) 173-189

JARVIE HP, NEAL C and WITHERS PJA (2006) Sewage-effluent phosphorus: A greater risk to river eutrophication than agricultural phosphorus? Sci. Total Environ. 360 (1-3) 246-253.

KIMBALL BA, RUNKEL RL, WALTON-DAY K and BENCALA KE (2002) Assessment of metal loads in watersheds affected by acid mine drainage by using tracer injection and synoptic sampling: Cement Creek, Colorado, USA. Appl. Geochem. 17 (9) 1183-1207.

LAUBE V, RAMAMOORTHY S and KUSHNER DJ (1979) Mobilization and accumulation of sediment bound heavy metals by algae. B. Environ. Contam. Toxicol. 21 (1) 763-770.

MAINSTONE CP and PARR W (2002) Phosphorus in rivers - ecology and management. Sci. Total Environ. 282-283 25-47.

MEY WS and VAN NIEKERK AM (2009) Evolution of Mine Water Management in the Highveld Coalfields. Proc. International Mine Water Conference, 19-23 October 2009, Pretoria, South Africa.

OBERHOLSTER PJ, MYBURGH JG, ASHTON PJ and BOTHA A-M (2010a) Responses of phytoplankton upon exposure to a mixture of acid mine drainage and high levels of nutrient pollution in Lake Loskop, South Africa. Ecotoxicol. Environ. Saf. 73 326-335.

OBERHOLSTER PJ, ANECK-HAHN NH, ASHTON PJ, BOTHA A-M, BROWN J, DABROWSKI JM, DE KLERK AR, DE KLERK LP, GENTHE B, GEYER H, HALL G, HILL L, HOFFMAN A, KLEYNHANS CJ, LAI J, LE ROUX W, LUUS-POWELL W, MASEKOAMENG E, McMILLAN P, MYBURGH J, SCHACHTSCHNEIDER K, SOMERSET V, STEYL J, SURRIDGE AKJ, SWANEVELDER ZH, VAN ZIJL MC, WILLIAMS C and WOODBORNE S (2010b) Risk Assessment of Pollution in Surface Waters of the Upper Olifants River System: Implications for Aquatic Ecosystem Health and the Health of Human Users of Water. CSIR Report No. CSIR/NRE/WR/IR/2011/0041/B. Council 
for Scientific and Industrial Research, Pretoria, South Africa.

OBERHOLSTER PJ and BOTHA A-M (2011) Dynamics of phytoplankton and phytobenthos in Lake Loskop (South Africa) and downstream irrigation canals. Fundam. Appl. Limnol. 179 (3) 169-178.

OBERHOLSTER PJ, MYBURGH JG, ASHTON PJ, COETZEE JJ and BOTHA A-M (2012) Bioaccumulation of aluminium and iron in the food chain of Lake Loskop, South Africa. Ecotoxicol. Environ. Saf. 76 (1) 134-141.

RAPSON LA and MOOLMAN CJ (2004) Identification of Abandoned and Defunct Collieries in the Witbank Area and the Ranking of Risk to Safety, Health and the Environment. COALTECH Research Association, Johannesburg, South Africa.

RODHE H, DENTENER F and SCHULZ M (2002) The global deposition of acidifying rain. Environ. Sci. Technol. 36 4382-4388.

SHORT TM, BLACK JA and BIRGE WJ (1990) Effects of acid-mine drainage on the chemical and biological character of an alkaline headwater stream. Arch. Environ. Con. Tox. 19 (2) 241-248.

TUTU H, MCCARTHY TS and CUKROWSKA E (2008) The chemical characteristics of acid mine drainage with particular reference to sources, distribution and remediation: The Witwatersrand Basin, South Africa as a case study. Appl. Geochem. 23 (12) 3666-3684.

VAN DEN BERG EC, PLARRE C, VAN DEN BERG HM and THOMPSON MW (2008) The South African National Land Cover 2000. Report No. GW/A/2008/86. Agricultural Research Council Institute for Soil, Climate and Water, Pretoria, South Africa.

VAN GINKEL CE (2011) Eutrophication: Present reality and future challenges for South Africa. Water SA 37 (5) 693-701.

VAN ZYL HC, MAREE JP, VAN NIEKERK AM, VAN TONDER GJ and NAIDOO C (2001). Collection, treatment and re-use of mine water in the Olifants River Catchment. J. S. Afr. I. Min. Metall. January/February 41-46.

WALKER WW (1996) Simplified procedures for eutrophication assessment and prediction: User manual, Instruction Report W-96-2. U.S. Army Engineer Waterways Experiment Station, Vicksburg, MS.

WORLD HEALTH ORGANIZATION (WHO) (2000) Air Quality Guidelines for Europe. ( $2^{\text {nd }}$ edn.). WHO Regional Publications, Europe Series, No. 91. World Health Organization, Regional Office for Europe, Copenhagen. 